\title{
Drug metabolism and hepatotoxicity
}

\author{
J M Tredger, M Davis
}

Drug metabolism in the 1960s

At the time the Liver Unit was established in 1966 , interest in the study of drug metabolism was growing, stimulated largely by the pharmaceutical industry, and the legislative requirements imposed upon it. It represented a remarkable change from the situation a few years previously when '. . . the study of the metabolism of foreign compounds was not a popular one; biochemists considered it rather a waste of time and effort, both of which could be better expended on looking at naturally occurring substances. Pharmacologists also had little interest in the subject and regarded it as unrelated to their immediate problems. Toxicology was in a primitive state of development and still largely concerned with cataloguing and describing the effects of various poisons'. ${ }^{1}$ By the $1960 \mathrm{~s}$, however, centres in Britain, Europe, and the United States had begun to characterise the drug metabolising enzymes and their responses to repeated drug ingestion. In 1966, novel discoveries emphasised: (i) the existence of more than one form of cytochrome P-450, ${ }^{2}$ the basic function $^{3}$ and characterisation ${ }^{45}$ of which had been defined only in the previous three years; (ii) the clinical implications of enzyme induction to drug therapy, as illustrated by three case reports, one describing fatal haemorrhage after withdrawal of the enzyme inducing sedative chloral hydrate in a patient on anticoagulants, ${ }^{6}$ and two showing relief of paediatric jaundice with phenobarbitone $;^{78}$ (iii) the hepatotoxicity of environmental toxins, after the outbreak of Epping jaundice resulting from contamination of flour with 4,4diamino-diphenylmethane. ${ }^{9}$ The limited understanding of the mechanisms of hepatotoxic drug reactions at that time can be gauged from a 1969 review by Schaffner and Raisfeld. ${ }^{10}$ An abundance of important interactions between chemicals and endogenous biochemical pathways had been documented, however, as exemplified in the review of carbon tetrachloride hepatotoxicity by Recknagel ${ }^{11}$ which continues to complement contemporary texts. ${ }^{12}$

In 1967 Conney published his almost timeless review of the agents responsible for enzyme induction in which he predicted that 'the genetic make-up of the individuals of a population within a given species may be important in determining the occurrence or magnitude of enzyme induction' ${ }^{13}$ Support for these prophesies was some years away, but the monitoring of enzyme induction in man and its clinical features and benefits was the starting point for the King's Liver Unit Drug Metabolism Group in 1966. Studies on the clinical value of phenobarbitone in the treatment of unconjugated hyperbilirubinaemia dominated the late $1960 \mathrm{~s}^{14-16}$ and prompted the search for alternative inducing therapies with fewer hypnotic side effects. ${ }^{17}$ In 1965 Aarts ${ }^{18}$ had suggested that urinary glucaric acid excretion might reflect hepatic drug metabolising enzyme activity. Over the next five years interest at King's centred around screening for enzyme induction by measuring the urinary excretion of this compound. ${ }^{19}$ The test was validated by showing an association with hepatic cytochrome P-450 content, ${ }^{20}$ and was used to show the enzyme inducing properties of drugs ${ }^{21}$ and environmental contaminants such as DDT. ${ }^{22}$ The observation that urinary D-glucaric acid excretion rose during the course of normal pregnancy indicated that changes in hepatic microsomal enzyme activity could be associated with endogenous compounds and physiological states. ${ }^{23}$ Other studies showed a correlation between urinary D-glucaric acid excretion and low circulating levels of calcium and folic acid in epileptic patients. ${ }^{24} 25$ This prompted the suggestion that the enzyme inducing properties of anticonvulsant drugs could lead to increased consumption and eventual deficiency of vitamin $\mathrm{D}$ and folic acid.

\section{The 1970s: the concepts of enzyme multiplicity} and covalent binding

There was worldwide activity in cataloguing the metabolism and effects of many hundreds of drugs and chemicals throughout the 1970s, not least in relation to the molecular features of enzyme induction and inhibition. A growing awareness emerged of the multiplicity of both phase I and phase II metabolising enzymes, with different forms showing a specific yet overlapping capacity to catalyse particular drug transformations, as well as a selective responsiveness to both enzyme inducers and inhibitors.

Perhaps the most significant advances of the $1970 \mathrm{~s}$ in relation to drug induced hepatotoxicity were the experimental observations by Gillette, Brodie and colleagues at the National Institutes of Health, USA, of the role played by reactive drug metabolites, ${ }^{26}$ their covalent binding to cellular macromolecules ${ }^{27}$ and the hepatoprotective role of glutathione. ${ }^{28}$ In retrospect, it is perhaps remarkable that 20 years had elapsed since the Millers had first observed a similar phenomenon in aminoazo dye induced carcinogenesis. ${ }^{29}$ Their comment in 1966 after 20 years work that '. . . we are still not in a position to define the molecular mechanism by which a chemical induces cancer' ${ }^{30}$ had a prophetic parallel in arguments that raged for many years on the relevance of covalent binding of reactive metabolites to chemical and drug induced liver damage.

The Liver Unit's interests in this area focused initially on paracetamol hepatotoxicity. ${ }^{31}$ Suicidal overdose with paracetamol was becoming increasingly common in Great Britain, ${ }^{32}$ and the growing number of referrals of such patients to the Liver Unit allowed the metabolic basis for hepatotoxicity from the drug to be studied in 


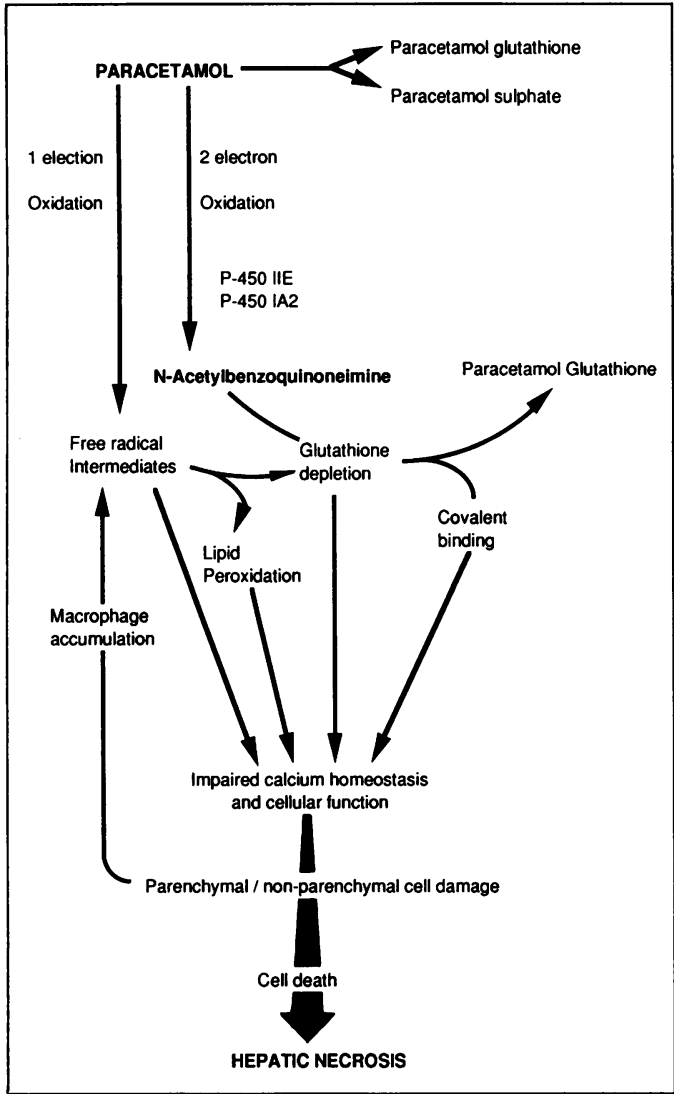

Figure 1: Current concepts in the mechanisms of paracetamol induced hepatotoxicity.

man. Early investigations showed that liver damage arises after ingestion of high doses of the drug when the balance in metabolism switches from the detoxication pathways of glucuronide and sulphate conjugation to cytochrome P-450dependent activation steps. ${ }^{33}$ This leads to an increased production of an unstable metabolite with the ability to bind irreversibly to liver cell proteins. Normally this metabolite is detoxified by conjugation with glutathione, but stores of this nucleophile become depleted leaving the reactive metabolite free to exert its toxic effects. By showing that the same mechanisms applied in $\operatorname{man}^{34}$ (Fig 1), the value of studies in animal models for developing treatment regimens was emphasised and stimulated the study of potential new antidotes. This led to the clinical use of methionine, ${ }^{35}$ cysteamine and dimercaprol, ${ }^{36}$ initiating an interest in the treatment of paracetamol induced fulminant hepatic failure discussed elsewhere in this volume.

\section{Idiosyncratic drug hepatotoxicity}

In the mid-1970s, no role had yet emerged for reactive metabolites in idiosyncratic drug toxicity (hepatotoxicity produced unpredictably by therapeutic doses of drugs in only a minority of susceptible individuals). Zimmerman, in his authoritative and still invaluable text of 1978 commented that 'relatively few experimental approaches have thrown any light on the hepatic injury caused by host idiosyncrasy. ${ }^{37}$ Within two years, however, important observations on individual variability in the rate of metabolism of drugs and in the responses to their potentially toxic metabolites was to transform this area.

It was well known that the capacity of an individual to acetylate drugs is genetically determined, ${ }^{38}$ with the population divided into rapid and slow acetylators. Research from St Mary's Hospital Medical School, London showed that a similar polymorphism applied to a pathway of oxidative metabolism, the hydroxylation of debrisoquine. ${ }^{39}$ This provided a potential for determining susceptibility to liver damage from some therapeutic agents as a result of differences in the rates at which individuals metabolised a drug through 'safe' or potentially hepatotoxic pathways. It was some years, however, before well characterised examples emerged. Thus, the half life of the antianginal drug, perhexiline maleate, is much prolonged in poor hydroxylators of debrisoquine ${ }^{40}$ and this seems to be associated with drug accumulation and microvesicular phospholipidosis. ${ }^{41}$ Different considerations apply to liver damage from the antituberculous drug isoniazid. Slow acetylators of the drug metabolise more through oxidation which can produce a reactive hydrazine derivative, and there is a higher incidence of liver damage amongst individuals with the slow acetylator phenotype. ${ }^{42}$ Genetic variations in oxidative metabolism are also likely to be important, as are responses to environmental influences. For example, concomitant exposure to rifampicin induces the metabolism of hydrazine and increases the risk of hepatotoxicity. ${ }^{43}$

Another factor determining susceptibility to some types of hepatotoxic drug reaction is the capacity to mount an immune response against drug altered liver components. A series of investigations carried out in the Liver Unit identified an antibody directed against a hepatocyte surface antigen altered by a halothane metabolite. ${ }^{44}$ The altered antigenic determinant probably results from oxidative halothane metabolism ${ }^{45}$ which generates trifluroacetylated proteins ${ }^{46-48}$ (Fig 2). It is likely that all individuals exposed to the drug generate altered hepatocyte membrane determinants, ${ }^{49}$ but only a small minority mount an immunological reaction against them. ${ }^{50}$ The fact that many patients with severe halothane hepatitis have circulating antibodies directed against other organs in the body ${ }^{51}$ strongly suggests an underlying, genetically determined defect in immune regulation. ${ }^{52}$ In contrast, some patients with hepatitis from the drug have no evidence of immune involvement, and liver damage in these cases is probably the result of overproduction of a hepatotoxic derivative produced by reductive halothane metabolism. Preferential stimulation of this pathway in experimental animals produces dose related hepatotoxicity ${ }^{53}$ (Fig 2).

Subsequently, the methods validated with halothane have been used to show a possible immune basis for drug hepatotoxicity from $\alpha$-methyldopa ${ }^{54}$ tienilic acid ${ }^{55}$ and ethanol. ${ }^{56}$ In addition to expressing an antibody reacting with tienilic acid derived neoantigens, more than $50 \%$ of patients with tienilic acid hepatitis produce an antibody ( $\alpha$-LKM2) directed against a cytochrome $\mathrm{P}-450$ II isoenzyme ( $\mathrm{P}-450$ 8; $\mathrm{P}-450$ $M P)$. Both this and the analogous LKM1 antibody ( $\alpha-P-450$ IID) have been associated with 


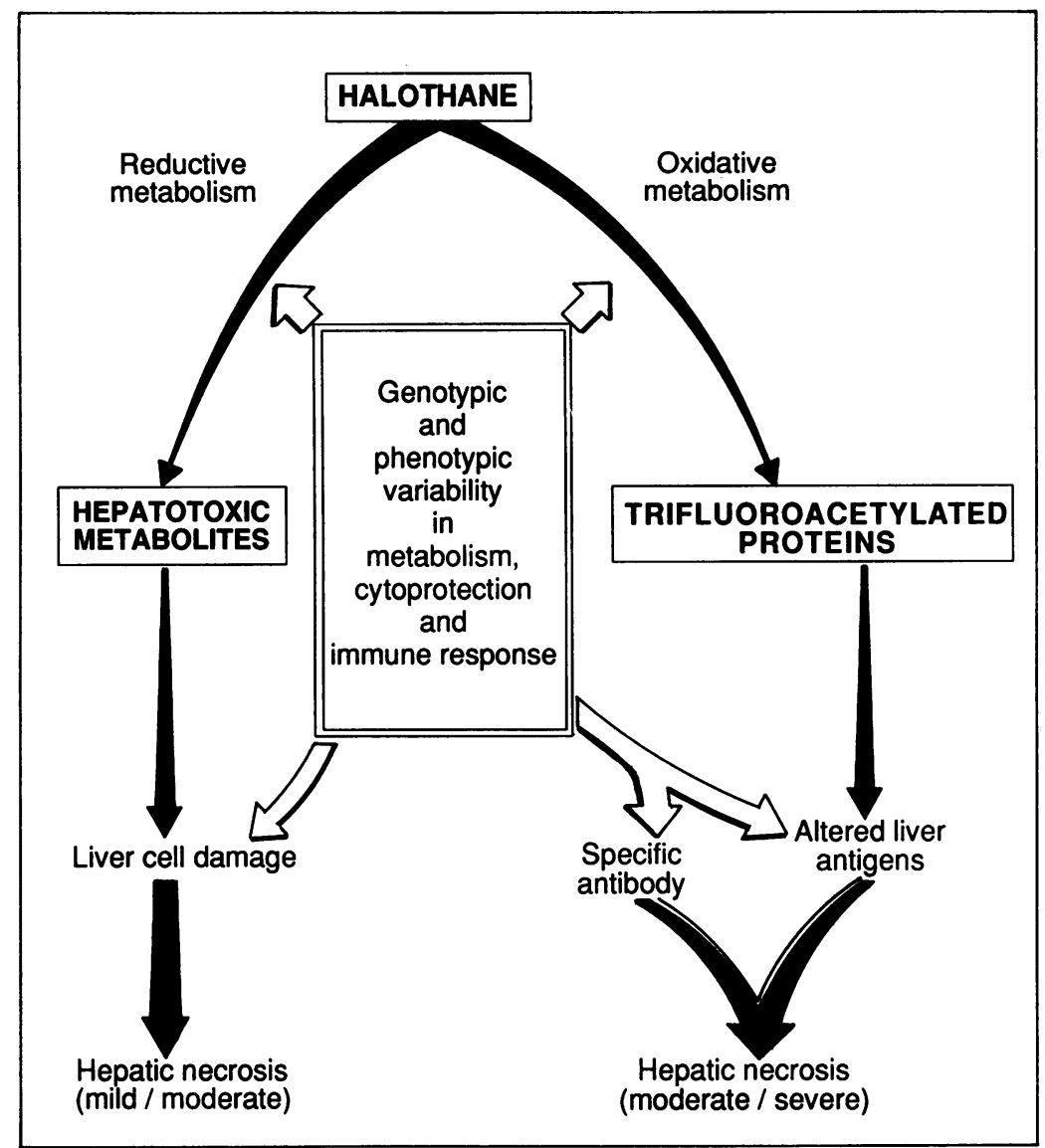

Figure 2: Mechanisms underlying predictable and immune mediated hepatotoxicity from halothane. drugs might influence that compound's metabolism and which agents could competitively inhibit its clearance. So arose the concept that P-450 doctors might emerge as a future subspeciality. ${ }^{61}$ Experimental studies in the Liver Unit were directed towards characterising the enzyme inducing properties of rifampicin. ${ }^{62}$ Clinically significant effects were demonstrated on corticosteroid requirements in asthmatics ${ }^{63}$ and on theophylline pharmacokinetics. $^{64}$ Rifampicin also induced the metabolism of testosterone and its hydroxylation at multiple sites on the molecule provided a powerful method for investigating enzyme induction. ${ }^{6566}$ The potential for urinalysis of endogenous steroid metabolites as a means of fingerprinting cytochrome P-450 isoenzyme profiles in individuals, however, was overtaken by the upsurge in molecular biology techniques. These not only added a further dimension to detection and characterisation, but also provided a long awaited basis for logical classification and nomenclature of a host of $\mathrm{P}-450$ s previously existing under numerous aliases.

In the late 1970s and early 1980s enormous information accrued on the potential mechanisms by which drugs caused and antidotes prevented hepatic damage. A large number of studies were carried out in vitro and used single end points such as covalent binding, depletion of intracellular glutathione or the impairment of cellular and biochemical events. The dangers of interpreting such in vitro observations in isolation soon became clear, however, stressing the value to toxicology of in vivo investigations for several reasons. First, the interplay between different enzymes acting on the same substrate was difficult to assess except in vivo, because drugs are not metabolised by a single isoenzyme. Secondly, competing detoxication pathways could determine a drug's toxic potential. In addition, non-parenchymal cells were increasingly being shown to be important in mediating and promulgating hepatotoxic events, ${ }^{67}$ and the emerging complexity and polymorphism of cytoprotective mechanisms could also influence susceptibility to tissue damage. Experimental studies in the Liver Unit confirmed that chronic ingestion of ethanol potentiated paracetamol hepatotoxicity, whereas acute administration provided a protective effect. ${ }^{68}$ These findings could not be explained solely by induction or inhibition of the enzymes producing the toxic metabolite, however, as had previously been considered to be the case ${ }^{69}$ and complementary roles for effects on glutathione depletion and intermediary metabolism were proposed. ${ }^{70}$ More recent evidence from convincingly large series of patients suggests that chronic alcohol consumption and anticonvulsant therapy adversely affect outcome after paracetamol overdose (Bray et al, in preparation). antibodies which competitively inhibited strate transformations. At the start of the decade, a role for gene probing of drug metabolising enzymes was still some way off, with no mention of it as an investigative tool made by Lu and West in their 1979 review of the multiplicity of cytochromes P-450. ${ }^{60}$ Accumulating knowledge, however, showed that association could be made between the metabolism of a specific drug and defined P-450 isoenzymes. This made it increasingly possible to predict which enzyme inducing

\section{From 1986 . . . to the future}

Advances over the past five years have deen factors regulating the control of drug metabolising enzymes, together with an increased understanding of the roles of glutathione and calcium dominated by the characterisation of genetic 


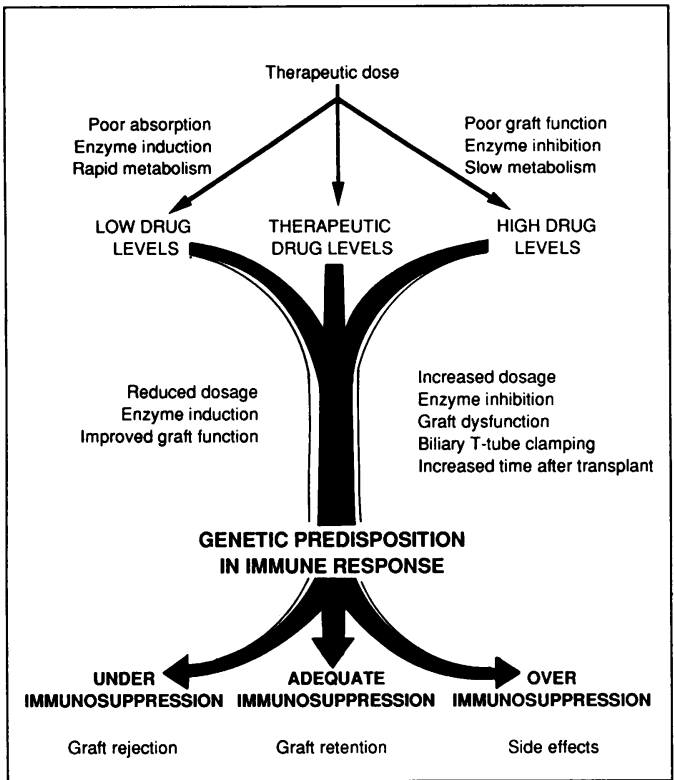

Figure 3: Pharmacological influences on the response to cyclosporine immunosuppression.

homeostasis in mediating and moderating tissue damage. Gene probing has provided a molecular basis for phenotypic expression of extensive and poor debrisoquine hydroxylation, where functionally defective gene products rather than complete gene deletions appear responsible. ${ }^{71}$ Parallel studies are strengthening links between the functional activities of structurally related isoenzymes across species; the extent of structural homology is providing clues as to the most appropriate animal models for drug metabolism in some cases. Experimental work is also beginning to clarify the role of endogenous compounds in regulating drug metabolism. For example, glucocorticoids have been shown to enhance the transcriptional activation of both cytochrome P-450 IA and glutathione $S$-transferase genes after enzyme induction by polycyclic aromatic hydrocarbons. ${ }^{72}$ The glutathione transferase isoenzymes are important in a transport and metabolic capacity and their polymorphism may contribute towards variability in the intracellular transport of drugs and the activity of detoxication pathways with glutathione. ${ }^{73}$ Also emerging has been the importance of subcellular glutathione pools and their relevance to the regulation and maintenance of organelle function - for example, the mitochondria. ${ }^{74}$ There is increasing interest in the role of interorgan glutathione homeostasis in determining toxic events outside the liver. For example, the kidney and lung extract glutathione from the plasma pool, which is apparently replenished only by the liver. Glutathione also maintains thiol/disulphide status, which in turn is crucial to the maintenance of subcellular integrity by calcium, so controlling the activity of plasma membrane ATPases, mitochondrial dehydrogenases and the activation of phospholipases and endonucleases. Disturbance of glutathione and calcium homeostasis is seen increasingly as a unifying mechanism in toxin related cell injury of different types. ${ }^{75}$

Recent studies in the Liver Unit have shown that $S$-adenosylmethionine is beneficial and possibly complementary to $N$-acetylcysteine, another glutathione precursor, in preventing experimentally induced paracetamol hepatotoxicity (Bray, Tredger, and Williams, in preparation). The benefit of late treatment with $\mathrm{N}$-acetylcysteine (after the $16 \mathrm{~h}$ limit previously suggested) for reducing mortality and preventing worsening encephalopathy in paracetamol induced fulminant hepatic failure has also been convincingly shown. ${ }^{76}$ Another late treatment studied experimentally was calcium channel blockade with diltiazem. This reduced paracetamol hepatotoxicity and stimulated regenerative activity when given to mice late after dosing with paracetamol when conventional antidotes had ceased to be maximally effective. ${ }^{77}$

\section{LIVER TRANSPLANTATION}

The increasing use of liver transplantation at King's has dominated research activity in the drug metabolism group over the last five years. Selection of patients for transplantation demanded improved methods for evaluating prognosis and rekindled an interest in evaluating liver function. Stimulated by Rudi Preisig's sabbatical visit in 1987, studies were made of the value of the cytochrome P-450 I-based caffeine clearance test but it was found susceptible to interference by intensive drug therapy in fulminant hepatic failure and after liver transplantation. ${ }^{78}$ Measurements of coagulation factors $\mathrm{V}$ and VIII showed no such interference and their value in predicting prognosis in paracetamolinduced fulminant hepatic failure ${ }^{79}$ and acute alcoholic hepatitis (Pereira, Langley, Bird et al, in preparation has been recently demonstrated.

The widespread use of cyclosporine after liver transplantation has stimulated Liver Unit research on drug monitoring and pharmacokinetics. Immunosuppression with cyclosporin is complicated in liver transplant recipients by the role played by the graft in influencing absorption (through bile production) as well as metabolism and the biliary excretion of metabolites. ${ }^{80}$ The majority of immunosuppressive activity is associated with the parent drug and management has been improved by specific monitoring of cyclosporin itself. The value of radioimmunoassay with a specific monoclonal antibody was validated in liver graft recipients, showing a close agreement of cyclosporine results with those measured by liquid chromatography. ${ }^{81}$ In later collaborative studies, the influence of biliary T-tube status and graft function on cyclosporine bioavailability and clearance was clearly observed. ${ }^{82}$ Recent technical developments in cyclosporine assay procedures have also been appraised, but there is a growing need for alternative methods to routine drug monitoring in evaluating the efficacy of immunosuppressive therapy, as Figure 3 illustrates. One option presently under consideration involves the screening of activation markers on peripheral blood lymphocytes (Gonde, Cohen, Tredger et al, in preparation).

It is clear that the future for research by the drug metabolism group in the Institute of Liver Studies will extend beyond the perspective of metabolism and hepatotoxicity. Continued research in particular areas of clinical relevance, 
however, such as paracetamol hepatotoxicity, seems assured. Here, and for many hepatotoxic drugs, characterisation of qualitative aspects of the covalent binding process is of obvious relevance. Obtaining evidence for the intracellular sites involved, the enzymes and cellular functions affected and the possibility of reversing such interactions is of high priority. This approach may be relevant to those drugs which are toxic directly through reactive metabolites and those invoking immune responses. For the latter, one emphasis in the immediate future must be to identify how drug related antigens are translocated to the cell surface, complementing investigations into the role of endogenous molecules such as cytochrome P-450 in autoimmune disease. Drug metabolists and immunologists together must then unravel the mechanisms underlying idiosyncrasy in immune mediated drug reactions. This may not only refine preclinical screening for drug toxicity, but will also lead to new treatment regimens to improve the safety of existing drugs.

The authors wish to thank all previous and current colleagues and the collaborators and sponsors whose support made our work possible.

1 Neuberger A, Smith RL. Richard Tecwyn Williams: The man, his work, his impact. Drug Metab Rev 1983; 14: 559 607.

2 Sladek NE, Mannering GJ. Evidence for a new cytochrome $P-450$ hemoprotein in hepatic microsomes from methylcholanthrene treated rats. Biochem Biophys Res Commun 1966; 24: 668-74.

3 Estabrook RW, Cooper DY, Rosenthal O. The light reversible carbon monoxide inhibition of the steroid $\mathrm{C} 2 \mathrm{l}$-hydroxylase carbon monoxide inhibition of the steroid C21-hydroxylase

4 Omura T, Sato R. The carbon monoxide binding pigment of liver microsomes. I. Evidence for its hemoprotein nature. $\mathcal{F}$ liver microsomes. I. Evidence

5 Omura T, Sato $R$. The carbon monoxide binding pigment of liver microsomes. II. Solubilization, purification and properties. F Biol Chem 1964; 239: 2379-85.

6 Cucinell SA, Odessky L, Weiss M, Dayton PG. The effect of chloral hydrate on bishydroxycoumarin metabolism. $₹ A M A$ 1966; 197: 366-8.

7 Yaffe SJ, Levy G, Matsuzawa T, Baliah T. Enhancement of glucuronide conjugating capacity in a hyperbilirubinaemic infant due to apparent enzyme induction by phenobarinfant due to apparent enzyme inductor
bitone. $N E n g l f$ Med 1966; 275: 1461-6.

8 Crigler JF, Gold N. Sodium phenobarbitone-induced disease in serum bilirubin in an infant with congenital nonhaemolytic jaundice and kernicterus. $\mathcal{F}$ Clin Invest 1966; 45: 998-9.

9 Kopelman H, Scheuer PJ, Williams R. The liver lesion of the Epping jaundice. Qf Med 1966; 35: 553-64.

10 Schaffner F, Raisfeld IH. Drugs and the liver: a review of metabolism and adverse reactions. Adv Intern Med 1969; 15: 221-51.

11 Recknagel RO. Carbon tetrachloride hepatotoxicity. Pharmacol Rev 1967; 19: 145-208.

12 Williams AT, Burk RF. Carbon tetrachloride hepatotoxicity: an example of free-radical-mediated injury. Semin Liv Dis 1990; 10: 279-84.

13 Conney AH. Pharmacological implications of microsomal enzyme induction. Pharmacol Rev 1967; 19: 317-66.

14 Thompson RPH, Williams R. Treatment of chronic intrahepatic cholestasis with phenobarbitone. Lancet 1967; ii: 646-8.

15 Thompson RPH, Strathers GM, Pilcher CWT, Robinson J, Williams $R$. Treatment of unconjugated jaundice with dicophane. Lancet 1969; ii: 4-7.

16 Thompson RPH, Eddleston ALWF, Williams R. Low plasma bilirubin in epileptics on phenobarbitone. Lancet 1969; i: 21-3.

17 Hunter J, Thompson RPH, Rake MO, Williams R. Controlled trial of phethnobarbital, a non-hypnotic barbiturate in
unconjugated hyperbilirubinaemia. $B M F$ 1971; ii: 497-9.

18 Aarts EM. Evidence for the function of D-glucaric acid as an indicator for drug-induced enhanced metabolism through the glucuronic acid

19 Williams R, Hunter J and Maxwell JD. Measurement of hepatic enzyme induction in man: use of B-glucaric acid hepatic enzyme induction in man: use of B-glucaric acid excretion test. In: Paumgartner G, Presig R, eds The liver: quantitat 1973.

20 Hunter JP, Maxwell JD, Stewart DA, Williams R. Urinary D-glucaric acid excretion and total liver content of cytochrome P-450 in guinea pigs: relationship during enzyme induction and following inhibition of protein synthesis. Biochem Pharmacol 1973; 22: 743-7.

21 Hunter J, Maxwell JD, Carrella M, Stewart DA, Williams R.
Urinary D-glucaric acid excretion as a test for hepatic enzyme induction in man. Lancet 1971 ; i: $572-5$.

22 Hunter J, Maxwell JD, Stewart DA, Williams R, Robinson J, Richardson A. Increased hepatic microsomal enzyme activity from occupational exposures to certain organ chlorine pesticides. Nature 1972; 237: 399-401.

23 Davis M, Simmons CJ, Dordoni B, Maxwell JD, Williams R. Induction of hepatic enzymes during normal human pregnancy. F Obstet Gynaecol Br Commonw 1973; 80: 690-4.

24 nancy. F Obstet Gynaecol Br Commonw 1973; 80: 690-4. Altered calcium metabolism in epileptic children on anticonvulsants. $B M F$ 1971; iv: $202-4$.

25 Maxwell JD, Hunter J, Stewart DA, Ardeman S, Williams R. Folate deficiency after anticonvulsant drugs: an effect of hepatic enzyme induction? BMF 1972; i: 297-9.

26 Mitchell JR, Jollow DJ, Potter WZ, Davis DC, Gillette JR Brodie BB. Acetaminophen-induced hepatic necrosis. I.
Role of drug metabolism. F Pharmacol Exp Ther 1973; 187: 185-94.

27 Jollow DJ, Mitchell JR, Potter WZ, Davis DC, Gillette JR, Brodie BB. Acetaminophen-induced hepatic mecrosis. II Role of covalent binding in vivo. F P harmacol Exp Ther 1973; 187: 195-202.

28 Mitchell JR, Jollow DJ, Potter WZ, Gillette JR, Brodie BB Acetaminophen-induced hepatic necrosis. IV. Protective Acetaminophen-induced hepatic necrosis. IV. Protective

29 Miller JA, Miller EC. The presence and signifiance of bound aminoazodyes in the livers of rats fed p-dimethylaminoazobenzene. Cancer Res 1947; 7: 468-80.

30 Miller EC, Miller JA. Mechanisms of chemical carcinogenesis. Nature of proximate carcinogens and interactions with macromolecules. Pharmacol Rev 1966; 18: 805-38.

31 Toghill PJ, Williams R, Stephens JD, Carroll JD. Acute hepatic necrosis following overdosage with paracetamol. Gastroenterology 1969; 56: 773-8.

32 Clark R, Thompson RPH, Borirakchanyavat V, Widdop B Davidson AR, Goulding R, Williams R. Hepatic damage and death from overdose of paracetamol. Lancet 1973; i: 66and

33 Davis M, Simmons CJ, Harrison NG, Williams R. Paracetamol overdose in man: relationship between pattern of urinary metabolites and severity of liver damage. $Q \mathcal{F ~ M e d}$ 1976; 45: 81-91.

34 Williams $\mathbf{R}$, Davis $M$ Therapeutic, clinical and experimental aspects of paracetamol overdose and hepatotoxicity including management of acute liver failure. In: Wickstron $\mathrm{E}$, Dybing E, eds. Acta Pharmacologica et Toxicologica. Proceedings of the 7th International Congress of the European Association of Poison Control Centres, Oslo, June 8-11, 1976. Copenhagen: Munksgaard 1977: 282-310.

35 Crome P, Volans GN, Vale JA, Widdop B, Gouding R, Williams R. The use of methionine for acute paracetamol poisoning. F Int Med Res 1976; 4: suppl 4: 112-7.

36 Hughes RD, Gazzard BG, Hanid MA, et al. Controlled trial of cysteamine and dimercaprol after paracetamol overdose. $B M \mathcal{F} 1977$; ii: 1395.

37 Zimmerman HJ. Drug Hepatotoxicity: the adverse effects of drugs and other chemicals on the liver. New York: Appleton-Century Crofts 1978.

38 Weber WW. Commentary: The molecular basis of hereditary acetylation polymorphism. Drug Metab Dispos 1986; 14: 377-81.

39 Evans DA, Mahgoub A, Sloan TP, Idle JR, Smith RL. A family and population study of the genetic polymorphism of debrisoquine oxidation in a white British population. $₹ \mathrm{M}$ ed Genet 1980; 17: 102-5.

40 Cooper RG, Evans DA, Price AH. Studies on the metabolism of perhexiline in man. Eur $\mathcal{F}$ Clin Pharmacol 1987; 32: 56976

41 Morgan MY, Reshef R, Shah RR, Oates NS, Smith RL, Sherlock S. Impaired oxidation of debrisoquine in patients with perhexiline liver injury. Gut 1984; 25: 1057-64.

42 Sarma GR, Immanuel C, Kailasam S, Narayana ASL, Venkatesan P. Rifampicin-induced release of hydrazine from isoniazid. Am Rev Resp Dis 1986; 133: 1072-5.

43 Davis M, Williams R. Textbook of adverse drug reactions 1991 (in

44 Vergani D, Mieli-Vergani G, Alberti A, et al. Demonstration of a circulating antibody reacting with the surface membrane of halothane-altered hepatocytes in patients with fulminant hepatitis following halothane anaesthesia. N Engl $\mathcal{F} \mathrm{Med}$ 1980; 303: 66-71.

45 Neuberger J, Mieli-Vergani G, Tredger JM, Davis $M$. Williams $\mathbf{R}$. Oxidative metabolism of halothane in the production of altered hepatocyte membrane antigens in acute halothane induced hepatic necrosis. Gut 1981; 22: 669-73.

46 Kenna JG, Neuberger J, Williams R. Identification by immunoblotting of three halothane-induced liver microsomal polypeptide antigens recognized by antibodies in sera from patients with halothane-associated hepatitis. $\mathcal{F}$ Pharmacol Exp Ther 1987; 424: 733-40.

47 Pohl L. Drug-induced allergic hepatitis. Semin Liver Dis 1990; 10: $305-15$.

48 Bird G, Williams R. Detection of antibodies to a halothane metabolite hapten in sera from patients with halothaneassociated hepatitis. F Hepatol 1989; 9: 366-73.

49 Kenna JG, Neuberger JM, Williams R. Identification in human liver of halothane induced neoantigens recognised by human liver of halothane induced neoantigens recognised by antibodies in sera from patien

50 Kenna JG, Neuberger J, Williams R. An enzyme-linked immunosorbent assay for detection of antibodies against immunosorbent assay for detection of antibodies against 1984; 75: 3-14.

51 Walton B, Simpson BR, Strunin L, Doniach D, Perrin J, 
Appleyard AJ. Unexplained hepatitis following halothane. $B M 71976$; i: $1171-6$.

52 Neuberger JM, Davis $M$. Advances in understanding of halothane hepatitis. Trends in Pharm Sci 1983; 4: 19-20.

53 Brown BR, Sipes IG. Biotransformation and hepatotoxicity of halothane. Biochem Pharmacol 1977; 26: 2091-4.

54 Neuberger J, Kenna JG, Nouri-Aria KT, Williams R. Antibody-mediated hepatocyte injury in methyl dop induced hepatotoxicity. Gut 1985; 26: 1233-9.

55 Neuberger J, Williams R. Immune-mediated mechanisms in tienilic acid associated hepatotoxicity. Gut 1989; 30: 515-9.

56 Crossley IR, Neuberger J, Davis M, Eddleston ALWF, Williams R. Ethanol metabolism in the generation of new antigenic determinants on liver cells. Gut 1986; 27: 186-7.

57 Manns M. Autoantibodies and antigens in liver diseases updated. f Hepatol 1989; 9: 272-80.

58 Popper H. Drug reactions and the liver. In: Davis M, Tredger JM, Williams R, eds. London: Pitman Medical 1981: 85

59 Watkins PB. Role of cytochromes P-450 in drug metabolism and hepatotoxicity. Semin Liv Dis 1990; 10: 235-50.

$60 \mathrm{Lu}$ AYH, West SB. The multiplicity of mammalian microsomal cytochromes P-450. Pharmacol Rev 1979; 31: 277-95

61 Conney AH. Induction of microsomal cytochrome P-450 enzymes: the first Bernard B. Brodie lecture at Pennsylvania enzymes: the first Bernard B. Brodie lecture at

62 Tredger JM, Smith HM, Powell-Jackson PR, Davis $M$ Williams R. Effect of rifampicin on the mouse hepatic mixed Willams R. Effect of rifampicin on the mouse hepatic mixed function

63 Powell-Jackson P, Heaton RW, Gray BJ, English J, Costello JF, Williams R. Adverse effect of rifampicin administratio on steroid-dependent asthma. Am Rev Resp Dis 1983; 128 307-10.

64 Powell-Jackson PJ, Jamieson AP, Gray BJ, Moxham J, Williams $R$. Effect of rifampicin administration on theophylline pharmacokinetics in humans. Am Rev Resp Dis 1985; 131: $939-40$.

65 Tredger JM, Smith HM, Davis M, Williams R. Use of a direct high performance liquid chromatography method for multiple testosterone hydroxylations in studies of microsomal ple testosterone hydroxylations in studies of microsoma monoox $729-36$.

66 Tredger JM, Smith HM, Williams R. Effects of ethanol and enzyme-inducing agents on the monooxygenation of testosterone and xenobiotics in rat liver microsomes. 7 Pharmacol Exp Ther 1984; 229: 292-9.

67 Laskin DL. Nonparenchymal cells and hepatotoxicity. Semin Liver Dis 1990; 10: 293-304.

68 Tredger JM, Smith HM, Read RB, Portmann B, Williams R. Effects of ethanol ingestion on the hepatotoxicity and metabolism of paracetamol in mice. Toxicology 1985; 36: 341-52.

69 Altomare E, Leo MA, Lieber CS. Interaction of acute ethano administration with acetaminophen metabolism and toxicity in rats fed alcohol chronically. Alcoholism: Clin Exp Res 1984; 8: 405-8.

70 Tredger JM, Smith HM, Read RB, Williams R. Effect of ethanol ingestion on the metabolism of a hepatotoxic dose of paracetamol in mice. Xenobiotica 1986; 7: 661-70.

71 Gonzales FJ, Skoda RC, Kimura S, et al. Characterization of the common genetic defect in humans deficient in debrisoquine metabolism. Nature 1988; 331: 442-6.

72 Prough RA, Sherratt AJ, Banet DE, Linder MW. Modulation of the polycyclic aromatic hydrocarbon-dependent induction of cytochrome P450IA1 by glucocorticoids. Drug Metab Rev 1989; 20: 585-99.

73 Boyer TD. The glutathione S-transferases: an update. Hepatology 1989; 9: 486-96.

74 Deleve LD, Kaplowitz N. Importance and regulation of hepatic glutathione. Semin Liver Dis 1990; 10: 251-66.

75 Reed DJ. Status of calcium and thiols in hepatocellular injury by oxidative stress. Semin Liver Dis 1990;10: 285-92.

76 Harrison PM, Keays R, Bray GP, Alexander GJM, Williams R. Improved outcome of paracetamol-induced fulminant hepatic failure by late administration of acetylcysteine. hepatic failure by late
Lancet 1990; 335: 1572-3.

77 Deakin CD Gove CD, Fagan EA, Tredger JM, Williams R. Delayed calcium channel blockade with diltiazem reduces paracetamol hepatotoxicity in mice. Human Exp Toxico 1991; 10: 119-23.

78 Nagel RA, Dirix LY, Hayllar KM, Preisig R, Tredger JM, Williams $R$. Use of quantitative liver function tests - caffeine clearance and galactose elimination capacity - after orthotopic liver transplantation. F Hepatol 1990; 10: 149-57.

79 Pereira LBMP, Langley PG, Hayllar KM, Tredger JM, Williams $R$. Coagulation factor $V$ and VIII/V ratio as predictors of outcome in paracetamol-induced fulminant hepatic failure: relation to other prognostic indicators. Gut 1991 (in press)

80 de Groen PC. Cyclosporine and the liver: how one affects the other. TRansplant Proc 1990; 22: 1197-202.

81 Tredger J, Steward CM, Williams R. Cyclosporin A blood levels: an evaluation of radioimmunoassay with selective monoclonal or polyclonal antibodies and high performance liquid chromatography in liver transplant recipients. Transplantation 1988; 46: 681-6.

82 Naoumov NV, Tredger JM, Steward CM, et al. Cyclosporin A pharmacokinetics in liver transplant recipients in relation to biliary T-tube clamping and liver dysfunction. Gut 1989; 30: $391-6$. 